\title{
Rapid and Efficient Plasmid Construction by Homologous Recombination in Yeast
}

\author{
Jolanda van Leeuwen, ${ }^{1,3}$ Brenda Andrews, ${ }^{1,2}$ Charles Boone, ${ }^{1,2}$ and Guihong Tan ${ }^{1,3}$ \\ ${ }^{1}$ Donnelly Centre for Cellular and Biomolecular Research, University of Toronto, Toronto, Ontario M5S 3E1, \\ Canada; ${ }^{2}$ Department of Molecular Genetics, University of Toronto, Toronto, Ontario M5S 3E1, Canada
}

The cloning of DNA fragments is a fundamental aspect of molecular biology. Traditional DNA cloning techniques rely on the ligation of an insert and a linearized plasmid that have been digested with restriction enzymes and the subsequent introduction of the ligated DNA into Escherichia coli for propagation. However, this method is limited by the availability of restriction sites, which often becomes problematic when cloning multiple or large DNA fragments. Furthermore, using traditional methods to clone multiple DNA fragments requires experience and multiple laborious steps. In this protocol, we describe a simple and efficient cloning method that relies on homologous recombination in the yeast Saccharomyces cerevisiae to assemble multiple DNA fragments, with 30-bp homology regions between the fragments, into one sophisticated construct. This method can easily be extended to clone plasmids for other organisms, such as bacteria, plants, and mammalian cells.

It is essential that you consult the appropriate Material Safety Data Sheets and your institution's Environmental Health and Safety Office for proper handling of equipment and hazardous material used in this protocol.

RECIPES: Please see the end of this protocol for recipes indicated by $<R>$. Additional recipes can be found online at http://cshprotocols.cshlp.org/site/recipes.

Reagents

Agarose gel (1.2\%) and electrophoresis reagents

Bacterial strains

Any standard Escherichia coli strain such as Top10 will suffice.

Deionized water (sterilized)

Dimethyl sulfoxide (DMSO)

dNTPs (10 mu)

Ethanol (70\%)

Glass beads $(0.4-0.6 \mathrm{~mm})$

Glycerol (10\%)

Isopropanol

Lithium acetate (LiAc)

${ }^{3}$ Correspondence: guihong.tan@utoronto.ca; jolanda.vanleeuwen@utoronto.ca

(c) 2015 Cold Spring Harbor Laboratory Press

Cite this protocol as Cold Spring Harb Protoc; doi:10.1101/pdb.prot085100 
J. van Leeuwen et al.

TABLE 1. Sequence of the oligonucleotides used in this protocol

\begin{tabular}{|c|c|}
\hline Name & Sequence $\left(5^{\prime}-3^{\prime}\right)$ \\
\hline ori-F & GATACTAACGCCGCCATCCAGTTTCCCGGGaaaggcggtaatacggtta \\
\hline ori-R & CCCGGGttgataatctcatgaccaaaatcc \\
\hline$a m p R-F$ & TGGTCATGAGATTATCAACCCGGGaaaggatcttcacctagatcct \\
\hline$a m p R-R$ & GGGcactttcggggaaatgtgcg \\
\hline CEN-F & GTTCCGCGCACATTTCCCCGAAAAGTGCCCGGGtcettttcatcacgtgc \\
\hline CEN-R & GGGcttaggacggatcgcttgC \\
\hline$L E U 2-\mathrm{F}$ & AGTTACAGGCAAGCGATCCGTCCTAAGCCCGGGaactgtgggaatactcaggt \\
\hline$L E U 2-\mathrm{R}$ & Cgtgtcgtttctattatgaatttc \\
\hline LYS2-F & TTTATAAATGAAATTCATAATAGAAACGACCCGGGcttcaatagtttgccagcg \\
\hline LYS2-R & GCTCCCGGGcatatcatacgtaatgctca \\
\hline URA3-F & TTGAGCATTACGTATGATATGCCCGGGagcttttcaattcatcttttttttttgttc \\
\hline URA3-R & GGGtaataactgatataattaaattgaagc \\
\hline HIS3-F & GCTTCAATTTAATTATATCAGTTATTACCCGGGcttcattcaacgtttcccatt \\
\hline HIS3-R & GGGtgatgcattaccttgtcatc \\
\hline kanR-F & TACTGAAGATGACAAGGTAATGCATCACCCGGGtagcccatacatccccatgt \\
\hline kanR-R & CCCGGGTAAATCACGCTAACATTTGA \\
\hline
\end{tabular}

All oligonucleotides are desalted and $<60 \mathrm{bp}$ in length. The sequences shown in lower case are homologous to sequences upstream (F) or downstream (R) of the template gene or origin; the sequences shown in upper case are homologous to one of the other fragments; the SmaI sites are underlined.

To prepare a 1 m solution, dissolve $10.2 \mathrm{~g}$ of LiAc in $100 \mathrm{~mL}$ of deionized water, filter-sterilize, and store at room temperature.

Luria-Bertani (LB) medium plus ampicillin $<\mathrm{R}>$

Lysis buffer for yeast $<\mathrm{R}>$

Milli-Q water

Oligonucleotides (desalted)

For a list of all the oligonucleotides used in this protocol, see Table 1.

Phenol (saturated)

Phusion high-fidelity DNA polymerase and buffer $(5 \times)$

For example, consider using Phusion Hot Start II DNA Polymerase (Thermo Scientific); kit includes bespoke buffers.

Plasmid miniprep kit

Polyethylene glycol (PEG) 3350

Prepare $100 \mathrm{~mL}$ of a $50 \%$ solution by dissolving $50 \mathrm{~g}$ of PEG3350 in $50 \mathrm{~mL}$ deionized water, adjusting the volume to $100 \mathrm{~mL}$ with deionized water, followed by filter sterilization.

Single-stranded DNA (ssDNA; e.g., Sigma-Aldrich D8899)

SmaI restriction endonuclease

Synthetic amino-acid-dropout medium $(\mathrm{SD}-\mathrm{all})<\mathrm{R}>$

Synthetic lysine-dropout medium (SD-lys) $<\mathrm{R}>$

Terrific broth (TB) medium $<$ R $>$

Tris-EDTA (TE) buffer $(10 \times)$

Add $0.2 \mathrm{~mL}$ of EDTA $(0.5 \mathrm{M}, \mathrm{pH}$ 8.0) and $1 \mathrm{~mL}$ of Tris-Cl $(1 \mathrm{~m}, \mathrm{pH}$ 8.0) to $99 \mathrm{~mL}$ of deionized water. Filtersterilize. Store at room temperature.

Yeast extract-peptone-dextrose $(\mathrm{YEPD})<\mathrm{R}>$

Yeast strains

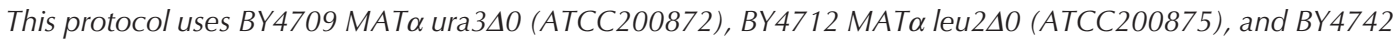

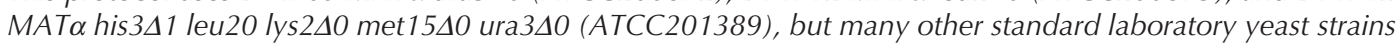
can also be used.

Equipment

Agarose gel electrophoresis materials

Benchtop centrifuge/microcentrifuge 
Electroporation system (e.g., MicroPulser by Bio-Rad)

Ice

Incubators $\left(30^{\circ} \mathrm{C}\right.$ and $\left.37^{\circ} \mathrm{C}\right)$

Microcentrifuge tubes $(1.5-\mathrm{mL})$

Orbital shaker

PCR tubes

Pipettes

Plates

Thermal cycler (PCR machine)

Vortex

Water bath $\left(42^{\circ} \mathrm{C}\right)$

To illustrate the cloning of multiple DNA fragments into one construct by homologous recombination, we describe the assembly of five different yeast selection markers (HIS3, LEU2, LYS2, URA3, and kanMX6) together with origins of replication for both yeast and E. coli (CEN6/ARS4 and ori) and an E. coli selection marker (ampR) into one plasmid (Fig. 1A).

A
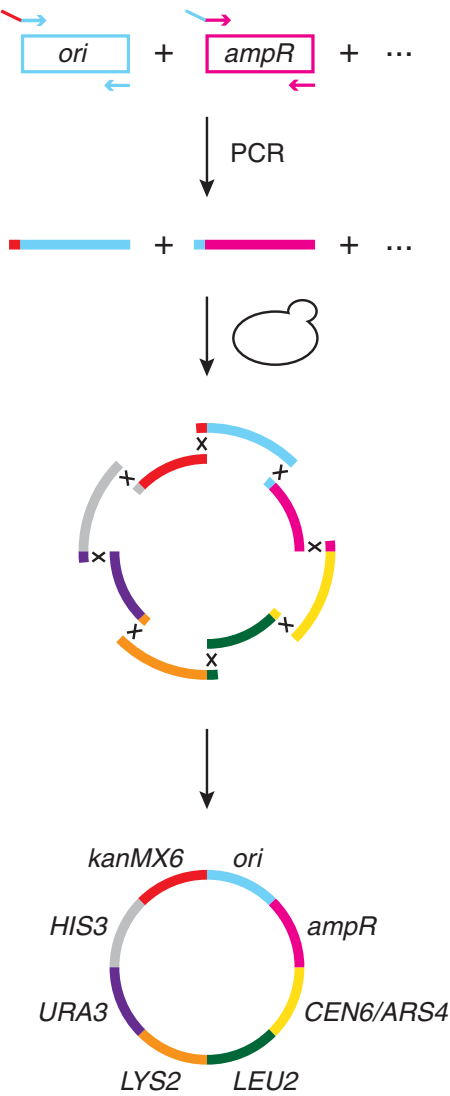

B

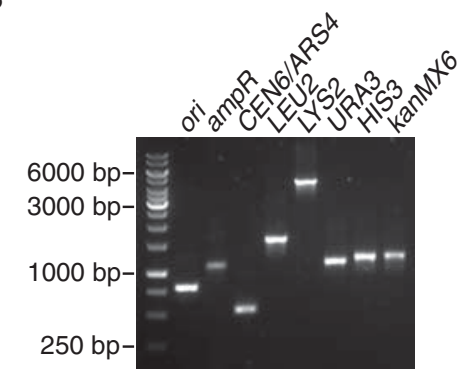

C
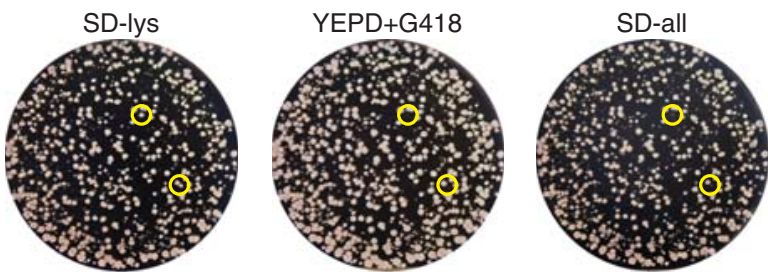

D
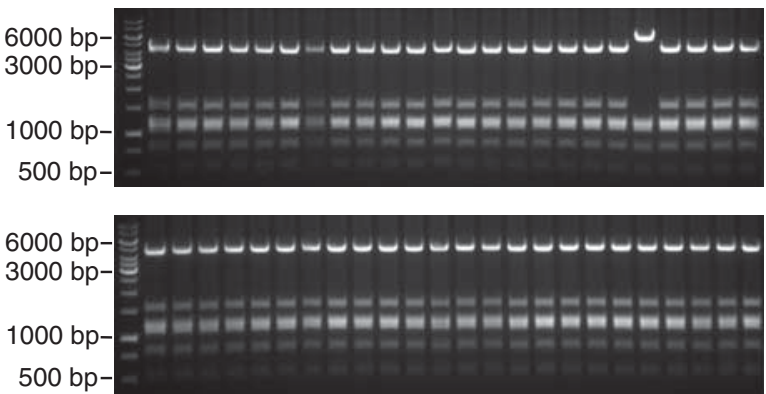

FIGURE 1. Rapid and efficient plasmid construction by homologous recombination in yeast. (A) A schematic representation of the described assembly of eight DNA fragments in yeast using 30-bp recombination sequences. $(B)$ The PCR fragments used in the featured assembly. (C) The selection of yeast transformants on synthetic lysine-dropout medium (SD-lys) and subsequent confirmation of the presence of the six fragments containing yeast sequences by replica plating on YEPD + G418 and synthetic-dropout medium without amino acids (SD-all). Only two transformants fail to grow after replica plating (yellow circles). (D) The Smal profiles of the final plasmids isolated from 24 yeast colonies (upper panel) or 24 E. coli colonies (lower panel). 
J. van Leeuwen et al.

\section{Preparation of DNA Fragments}

This procedure should take 3-4 h on day 1.

1. Prepare genomic DNA from a mixture of the yeast strains BY4709 and BY4712 to serve as a template in the polymerase chain reaction (PCR) (see Steps 23-35).

2. Prepare a $20-\mu \mathrm{L}$ PCR.

Sterile deionized water

Buffer (5x)

dNTP mixture (10 mM)

Forward primer $(10 \mu \mathrm{M})$

Reverse primer $(10 \mu \mathrm{M})$

Template DNA

Phusion DNA polymerase

$$
\begin{gathered}
13.4 \mu \mathrm{L} \\
4 \mu \mathrm{L} \\
0.4 \mu \mathrm{L} \\
0.5 \mu \mathrm{L} \\
0.5 \mu \mathrm{L} \\
1 \mu \mathrm{L} \\
0.2 \mu \mathrm{L}
\end{gathered}
$$

3. Use the following PCR cycling conditions.

$\begin{array}{ll}\text { Initial denaturation } & 60 \mathrm{sec} \text { at } 98^{\circ} \mathrm{C} \\ 5 \mathrm{Cycles} & 10 \mathrm{sec} \text { at } 98^{\circ} \mathrm{C}, 20 \mathrm{sec} \text { at } 55^{\circ} \mathrm{C} \text {, and } 90 \mathrm{sec} \text { at } 72^{\circ} \mathrm{C} \\ 25 \mathrm{Cycles} & 10 \mathrm{sec} \text { at } 98^{\circ} \mathrm{C}, 20 \mathrm{sec} \text { at } 62^{\circ} \mathrm{C} \text {, and } 90 \mathrm{sec} \text { at } 72^{\circ} \mathrm{C}\end{array}$

HIS3, LEU2, LYS2, and URA3 can be amplified from 100 ng of genomic DNA of a mixture of the yeast strains BY4709 and BY4712. CEN6/ARS4, ampR, and ori can be amplified from 1 pg of pRS416 (Sikorski and Hieter 1989), and kanMX6 can be amplified from 1 pg of pFA6-kanMX6 (Bahler et al. 1998).

4. Run $2 \mu \mathrm{L}$ of each PCR product on a $1.2 \%$ agarose gel (Fig. 1B).

If a PCR product contains multiple fragments, all fragments can potentially be assembled in the final construct. In this case, purification of the correct PCR product from the gel might be necessary. Alternatively, the unpurified PCR product with multiple fragments can be used, in which case the number of colonies that have to be screened for the expected construct has to be increased.

The PCR products can be stored at $4^{\circ} \mathrm{C}$ or $-20^{\circ} \mathrm{C}$.

\section{Preparation of Competent Yeast Cells}

The following procedure is a modified version of Gietz's method (Gietz and Woods 2002) and should take 5 min on day 1 and $10-15$ min on day 2.

5. Patch the yeast strain BY4742 on a $2-\mathrm{cm}^{2}$ area on YEPD agar and incubate overnight at $30^{\circ} \mathrm{C}$.

Alternatively, the yeast strain can be used to inoculate a 5-mL culture of liquid YEPD medium. Incubate overnight at $30^{\circ} \mathrm{C}$ while shaking on an orbital shaker at $200 \mathrm{rpm}$. Any standard laboratory yeast strain, such as BY4741 or W303, can be used instead of BY4742.

6. Scrape a $50-\mu \mathrm{L}$ portion of yeast cells from the YEPD plate and resuspend the cells in $1 \mathrm{~mL}$ of sterile deionized water in a $1.5-\mathrm{mL}$ microcentrifuge tube.

Alternatively, harvest $1-1.5 \mathrm{~mL}$ of a liquid culture.

7. Pellet the cells by centrifugation at $3000 \mathrm{rpm}$ ( $800 \mathrm{rcf}$ ) for $1 \mathrm{~min}$ at room temperature in a microcentrifuge and discard the supernatant.

8. Wash the pellet once with $1 \mathrm{~mL}$ of $0.1 \mathrm{~m}$ LiAc.

9. Estimate the volume of the cell pellet and resuspend the cells in an equal volume of $0.1 \mathrm{M} \mathrm{LiAc}$ supplemented with $10 \%$ glycerol.

By using larger volumes of liquid culture in Steps 5 and 6, a large amount of competent cells can be made at once. These competent cells can be stored at $-80^{\circ} \mathrm{C}$ in $0.1 \mathrm{M}$ LiAc supplemented with $10 \%$ glycerol.

Yeast Transformation

This procedure is a modified version of Gietz's method (Gietz and Woods 2002) and should take 3 h (not including the time needed to grow the yeast cells) on day 2. 
10. Prepare the transformation buffer by mixing $800 \mu \mathrm{L}$ of 50\% PEG3350, $100 \mu \mathrm{L}$ of $1 \mathrm{M} \mathrm{LiAc}, 100 \mu \mathrm{L}$ of $10 \times \mathrm{TE}$, and $50 \mu \mathrm{L}$ of DMSO.

11. Boil the ssDNA ( $10 \mathrm{mg} / \mathrm{mL})$ for $5 \mathrm{~min}$ and place it on ice.

12. Add $\sim 100 \mathrm{ng}$ of each DNA fragment, $2 \mu \mathrm{L}$ of ssDNA, and $12 \mu \mathrm{L}$ of competent yeast cells into a $1.5-\mathrm{mL}$ microcentrifuge tube; mix gently by pipetting up and down.

If the total volume of all the DNA fragments together is $>20 \mu L$, the overall transformation efficiency will decrease. The volume can be reduced by air-drying the DNA overnight at room temperature.

13. Add $100 \mu \mathrm{L}$ of the transformation buffer from Step 10 and vortex for $\sim 10 \mathrm{sec}$.

14. Incubate for $30 \mathrm{~min}$ at room temperature.

15. Incubate for $15 \mathrm{~min}$ in a $42^{\circ} \mathrm{C}$ water bath.

16. Incubate on ice for $5 \mathrm{~min}$.

17. Pellet the cells by centrifugation at $3000 \mathrm{rpm}$ ( $800 \mathrm{rcf}$ ) for $1 \mathrm{~min}$ and remove the supernatant.

18. Resuspend the cells in $1 \mathrm{~mL}$ of YEPD.

19. (Optional) Incubate the cells for $2 \mathrm{~h}$ at $30^{\circ} \mathrm{C}$.

This step allows the cells to produce the antibiotic resistance and/or auxotrophic marker proteins before applying selection and thereby increases the overall transformation efficiency.

20. Plate $250 \mu \mathrm{L}$ of the cell suspension on SD-lys plates.

Other media that select for one of the other cloned genes can also be used.

21. Incubate the plates for $2-3 \mathrm{~d}$ at $30^{\circ} \mathrm{C}$.

22. Replica-plate the colonies on SD-all and YEPD + G418 plates (Fig. 1C).

The SD-lys plates select only for one of the yeast markers (LYS2) and for presence of the CEN6/ARS4. This replica-plating step tests whether the other yeast selection markers are present in the construct and functional. We have obtained 470 colonies on the SD-lys plate, only two of which failed to grow on the YEPD + G418 (which selects for kanMX6) and SD-all (which selects for HIS3, LEU2, and URA3) plates.

\section{Preparation of Yeast Genomic DNA}

This procedure should take $1 \mathrm{~h}$ on day 4.

23. Wash all the colonies from the SD-lys plate from Step 21 using $5 \mathrm{~mL}$ of sterile water and transfer $1 \mathrm{~mL}$ of cells to a $1.5-\mathrm{mL}$ microcentrifuge tube.

24. Pellet the cells by centrifugation at $3000 \mathrm{rpm}$ ( $800 \mathrm{rcf}$ ) for $1 \mathrm{~min}$ and remove the supernatant.

25. Resuspend the pellet in $250 \mu \mathrm{L}$ of lysis buffer for yeast.

26. Add $250 \mu \mathrm{L}$ of saturated phenol and $\sim 200 \mu \mathrm{L}(\sim 200 \mathrm{mg})$ of glass beads.

27. Close the cap tightly and vortex for $>2 \mathrm{~min}$ at room temperature.

28. Centrifuge at $13,000 \mathrm{rpm}(15,700 \mathrm{rcf})$ for $5 \mathrm{~min}$.

29. Transfer $150 \mu \mathrm{L}$ of the aqueous top layer to a new $1.5-\mathrm{mL}$ microcentrifuge tube and centrifuge again at 13,000 rpm (15,700 rcf) for $5 \mathrm{~min}$.

30. Transfer $100 \mu \mathrm{L}$ of the top layer to a new $1.5 \mathrm{~mL}$ microcentrifuge tube, add $100 \mu \mathrm{L}$ of $100 \%$ isopropanol and mix thoroughly by inversion.

31. Centrifuge at $13,000 \mathrm{rpm}(15,700 \mathrm{rcf})$ for $10 \mathrm{~min}$ and remove the supernatant.

32. Wash the pellet once with $500 \mu \mathrm{L}$ of $70 \%$ ethanol.

33. Briefly centrifuge at $13,000 \mathrm{rpm}(15,700 \mathrm{rcf})$ for $10 \mathrm{sec}$ and remove the remaining ethanol.

34. Dry the pellet at room temperature for $\sim 10 \mathrm{~min}$.

35. Dissolve the pellet in $40 \mu \mathrm{L}$ of sterile water. 
J. van Leeuwen et al.

\section{Preparation of Competent E. coli Cells}

This procedure should take $10 \mathrm{~min}$ on day 4.

36. Inoculate $2 \mathrm{~mL}$ of $\mathrm{TB}$ using one bacterial colony and incubate overnight at $37^{\circ} \mathrm{C}$ while shaking at $250 \mathrm{rpm}$.

In the example described here, we use Top10 cells.

37. Add $2 \mathrm{~mL}$ of $\mathrm{TB}$ and incubate for another $25 \mathrm{~min}$ at $37^{\circ} \mathrm{C}$ while shaking at $250 \mathrm{rpm}$ in an orbital shaker.

38. Divide the culture into aliquots of $1 \mathrm{~mL}$.

This is approximately the amount of culture needed for one transformation.

39. Collect the cells by centrifuging at $13,000 \mathrm{rpm}(15,700 \mathrm{rcf})$ for $1 \mathrm{~min}$.

40. Wash the cells four times with Milli-Q water.

41. Estimate the volume of the cell pellet and resuspend the cells in an equal volume of Milli-Q water.

More water (up to five times the volume of the cell pellet) can be used to obtain "more" competent cells. However, the transformation efficiency will slightly decrease because the cells are more diluted. By using greater volumes of liquid culture in Steps 36-41, a large number of competent cells can be made at once. These competent cells can be stored at $-80^{\circ} \mathrm{C}$ in $10 \%$ glycerol.

Other methods can be used to make competent $\mathrm{E}$. coli cells, but these will require longer preparation times. Also, with this method, all the steps after growing the culture can be performed at room temperature, which makes it more straightforward and robust.

\section{Plasmid Recovery from Escherichia coli}

This procedure should take $\sim 5$ on day 5 and day 6 .

42. Add $20 \mu \mathrm{L}$ of competent E. coli cells to a $200-\mu \mathrm{L}$ PCR tube and add $0.5 \mu \mathrm{L}$ of yeast genomic DNA.

43. Mix the DNA with the competent cells by pipetting up and down.

44. Transfer the mixture to an electroporation cuvette (1 mm gap).

45. Electroporate the cells according to the manufacturer's manual.

46. Add $250 \mu \mathrm{L}$ of LB and plate all the cells on an LB plate containing ampicillin.

Note that kanMX6 is functional in both $\mathrm{S}$. cerevisiae and $\mathrm{E}$. coli. Therefore, transformants can also be selected on LB media containing kanamycin.

47. Incubate the plates overnight at $37^{\circ} \mathrm{C}$.

48. Purify the plasmid DNA with a plasmid miniprep kit.

49. Confirm the correct assembly of the fragments by a SmaI digestion (Fig. 1D).

In the example described here, Smal restriction sites were added to each fragment by means of the primers to show the accuracy of homologous recombination in yeast. However, the addition of restriction sites is not necessary for this method.

Homologous recombination in yeast has been successfully used in the cloning of both natural and synthetic DNA fragments (Ma et al. 1987; Wang 2000; Chen et al. 2005; Gibson et al. 2008a,b; Gibson 2009; Shao and Zhao 2009; Tan and Tan 2010; Tsvetanova et al. 2011; Liang et al. 2012; Shao and Zhao 2013). However, many of these methods are based on yeast-bacterial shuttle plasmids, which rather restricted the technology to a small niche within molecular biology. For an introduction to these technologies, see Introduction: Construction of Multifragment Plasmids by Homologous Recombi- 
nation in Yeast (van Leeuwen et al. 2015). Recently, however, Kuijpers et al. (2013) have presented an efficient strategy for assembling a plasmid from mutiple DNA fragments by using overlapping homology regions of $60 \mathrm{bp}$. As this method does not make use of a vector backbone, it can easily be extended to construct plasmids for other organisms.

In this protocol, we have described the use of yeast as a host to assemble eight DNA fragments, with short homology regions $(30 \mathrm{bp}$ ) between the fragments, into one plasmid (Fig. 1A). Equal amounts of PCR products were cotransformed into yeast, and transformants were selected on synthetic media lacking lysine (SD-lys), which confirms the presence and functionality of LYS2 and the CEN6/ARS4 origin of replication. The presence and activity of HIS3, LEU2, URA3, and kanMX6 were confirmed by replica plating (Step 22). Only two out of 470 transformants selected on SD-lys failed to grow after replica plating. The genomic DNA was individually purified from 24 randomly picked yeast colonies from the SD-lys plate and from 24 randomly picked E. coli colonies from Steps 46-48, followed by recovery of the plasmids. SmaI sites were introduced between all the fragments when the primers were designed, which enabled confirmation of the correct assembly of the construct by a SmaI digestion. In one out of the 48 isolated plasmids, a SmaI site was missing, which could be caused by impurities in the primers used, whereas the other 47 plasmids all showed the expected DNA bands (Fig. 1D). Based on the growth phenotypes on the different media and the SmaI digestion profiles, we can conclude that the overall assembly efficiency is $>95 \%$.

This protocol uses short $(<60 \mathrm{bp})$, desalted oligonucleotides and unpurified PCR products. This makes the method highly cost- and time-efficient, especially when cloning multiple fragments. We modified the yeast and bacterial transformation methods, which facilitates high-throughput cloning. However, this method has the common disadvantage that inserts that are toxic to either yeast or bacteria cannot be cloned. Also, because homologous recombination is so efficient in yeast, the cloning of inverted or repetitive sequences can be problematic.

Interestingly, we have found that the kanMX6 selector module is functional both in yeast and bacteria, which reduces the number of required selection markers from two (one for yeast and one for E. coli) to one. Although, in the example described here, separate fragments are used for the E. coli selection marker and origin of replication ( $\operatorname{ampR}$ and $o r i)$, we have routinely used the shortest backbone of pBlueScript II (Alting-Mees and Short 1989), which contains both ori and ampR, as one fragment in our assemblies. Finally, this method can be extended to clone constructs for other organisms by combining one or more fragment(s) with the genes or sequences of interest with a fragment containing a linearized nonyeast plasmid, and another fragment containing a CEN/ARS origin and yeast selection marker.

Luria-Bertani (LB) Medium Plus Ampicillin

\begin{tabular}{lc} 
Reagent & Quantity \\
\hline Agar & $20 \mathrm{~g}$ \\
$\mathrm{NaCl}$ & $10 \mathrm{~g}$ \\
Tryptone & $10 \mathrm{~g}$ \\
Yeast extract & $5 \mathrm{~g}$
\end{tabular}

Prepare the above-listed ingredients in $1 \mathrm{~L}$ of deionized water. Adjust the $\mathrm{pH}$ to 7.0 with $5 \mathrm{~N} \mathrm{NaOH}$. Autoclave for $20 \mathrm{~min}$ at $15 \mathrm{psi}\left(1.05 \mathrm{~kg} / \mathrm{cm}^{2}\right)$. Cool to $\sim 60^{\circ} \mathrm{C}$ and add ampicillin (final concentration $120 \mu \mathrm{g} / \mathrm{mL}$ ). Pour the medium into Petri dishes ( $\sim 25 \mathrm{~mL}$ per $100-\mathrm{mm}$ plate). Store the LB plates at $4^{\circ} \mathrm{C}$; they will keep for at least 4 mo. 
J. van Leeuwen et al.

Lysis Buffer for Yeast

\begin{tabular}{lcc} 
Reagent & Quantity & Final concentration \\
\hline Triton X-100 & $10 \mathrm{~mL}$ & $2 \%(\mathrm{v} / \mathrm{v})$ \\
$\mathrm{SDS}(10 \%)$ & $50 \mathrm{~mL}$ & $1 \%(\mathrm{w} / \mathrm{v})$ \\
$\mathrm{NaCl}(5 \mathrm{M})$ & $10 \mathrm{~mL}$ & $100 \mathrm{~mm}$ \\
$\operatorname{Tris}-\mathrm{Cl}(1 \mathrm{M}, \mathrm{pH} 8.0)$ & $5 \mathrm{~mL}$ & $10 \mathrm{mM}$ \\
EDTA $(0.5 \mathrm{M}, \mathrm{pH} 8.0)$ & $1 \mathrm{~mL}$ & $1 \mathrm{mM}$
\end{tabular}

Prepare in $500 \mathrm{~mL}$ of deionized water. Autoclave for $20 \mathrm{~min}$ at $15 \mathrm{psi}\left(1.05 \mathrm{~kg} / \mathrm{cm}^{2}\right)$. Store at room temperature; it will keep for at least $1 \mathrm{yr}$.

Supplements for SD-Lys

\begin{tabular}{lc} 
Reagent & Quantity \\
\hline L-Leucine & $0.84 \mathrm{~g}$ \\
L-Histidine HCl & $0.42 \mathrm{~g}$ \\
L-Methionine & $0.42 \mathrm{~g}$ \\
Uracil & $0.25 \mathrm{~g}$
\end{tabular}

In separate tubes, prepare $100 \times$ stocks of each of the four reagents by dissolving the quantities indicated in $100 \mathrm{~mL}$ of deionized water and then filter-sterilizing. Store all stocks at room temperature; they will keep for at least 6 mo.

Synthetic Amino-Acid-Dropout Medium (SD-AII)

\begin{tabular}{lcc} 
Reagent & Quantity & Final concentration \\
\hline $\begin{array}{l}\text { Difco yeast nitrogen base } \\
\quad \text { without amino acids }\end{array}$ & $6.7 \mathrm{~g}$ & $6.7 \mathrm{~g} / \mathrm{L}$ \\
Agar & $20 \mathrm{~g}$ & $20 \mathrm{~g} / \mathrm{L}$ \\
Dextrose $(40 \%)$ & $50 \mathrm{~mL}$ & $20 \mathrm{~g} / \mathrm{L}$
\end{tabular}

Add $950 \mathrm{~mL}$ of deionized water to $6.7 \mathrm{~g}$ Difco yeast nitrogen base without amino acids and $20 \mathrm{~g}$ of agar. Autoclave for $20 \mathrm{~min}$ at $15 \mathrm{psi}\left(1.05 \mathrm{~kg} / \mathrm{cm}^{2}\right)$. After autoclaving, add $50 \mathrm{~mL}$ of a $40 \%$ dextrose solution. Cool the medium to $\sim 60^{\circ} \mathrm{C}$ and pour into Petri dishes ( $25 \mathrm{~mL}$ per $100-\mathrm{mm}$ plate). Store the $\mathrm{SD}$-all plates at $4^{\circ} \mathrm{C}$; they will keep for at least 6 mo.

Synthetic Lysine-Dropout Medium (SD-Lys)

\begin{tabular}{|c|c|c|}
\hline Reagent & Quantity & Final concentration \\
\hline $\begin{array}{l}\text { Difco yeast nitrogen base } \\
\text { without amino acids }\end{array}$ & $6.7 \mathrm{~g}$ & $6.7 \mathrm{~g} / \mathrm{L}$ \\
\hline Agar & $20 \mathrm{~g}$ & $20 \mathrm{~g} / \mathrm{L}$ \\
\hline \multicolumn{3}{|l|}{ Supplements for SD-lys: } \\
\hline L-Leucine $(100 \times)$ & $10 \mathrm{~mL}$ & $8.4 \mathrm{mg} / \mathrm{L}$ \\
\hline L-Histidine $\mathrm{HCl}(100 \times)$ & $10 \mathrm{~mL}$ & $4.2 \mathrm{mg} / \mathrm{L}$ \\
\hline L-Methionine $(100 \times)$ & $10 \mathrm{~mL}$ & $4.2 \mathrm{mg} / \mathrm{L}$ \\
\hline Uracil (100×) & $10 \mathrm{~mL}$ & $2.5 \mathrm{mg} / \mathrm{L}$ \\
\hline Dextrose $(40 \%)$ & $50 \mathrm{~mL}$ & $20 \mathrm{~g} / \mathrm{L}$ \\
\hline \multicolumn{3}{|c|}{$\begin{array}{l}\text { Combine } 10 \mathrm{~mL} \text { of each of the SD-lys supplements }(100 \times \text { L-leucine, } 100 \times \text { L-histidine } \mathrm{HCl}, 100 \times \\
\mathrm{L}-\text {-methionine, } 100 \times \text { uracil) with } 6.7 \mathrm{~g} \text { of Difco yeast nitrogen base without amino acids and } 20 \mathrm{~g} \\
\text { agar, and add } 950 \mathrm{~mL} \text { of deionized water. Autoclave for } 20 \mathrm{~min} \text { at } 15 \mathrm{psi}\left(1.05 \mathrm{~kg} / \mathrm{cm}^{2}\right) \text {. After auto- } \\
\text { claving, add } 50 \mathrm{~mL} \text { of a } 40 \% \text { dextrose solution. Cool the medium to } \sim 60^{\circ} \mathrm{C} \text { and pour into Petri dishes } \\
\left(\sim 25 \mathrm{~mL} \text { per } 100-\mathrm{mm} \text { plate). Store the SD-lys plates at } 4^{\circ} \mathrm{C} \text {; they will keep for at least } 6 \text { mo. (Note that }\right. \\
\text { this recipe is optimized for BY } 4742 \text { strains. It should be adjusted if another yeast strain is used as a } \\
\text { recombination host.) }\end{array}$} \\
\hline
\end{tabular}


Terrific Broth (TB) Medium

\begin{tabular}{lrc} 
Reagent & Quantity & Final concentration \\
\hline Yeast extract & $24 \mathrm{~g}$ & $24 \mathrm{~g} / \mathrm{L}$ \\
Tryptone & $20 \mathrm{~g}$ & $20 \mathrm{~g} / \mathrm{L}$ \\
Glycerol & $4 \mathrm{~mL}$ & $4 \mathrm{~mL} / \mathrm{L}$ \\
Phosphate buffer $\left(0.17 \mathrm{M} \mathrm{KH}_{2} \mathrm{PO}_{4}\right.$, & $100 \mathrm{~mL}$ & $0.017 \mathrm{M} \mathrm{KH} \mathrm{PO}_{4}$, \\
$\left.\quad 0.72 \mathrm{M} \mathrm{K}_{2} \mathrm{HPO}_{4}\right)$ & & $0.072 \mathrm{M} \mathrm{K}_{2} \mathrm{HPO}_{4}$
\end{tabular}

Add $900 \mathrm{~mL}$ of deionized water to $24 \mathrm{~g}$ of yeast extract, $20 \mathrm{~g}$ of tryptone, and $4 \mathrm{~mL}$ of glycerol. Shake or stir until the solutes have dissolved and sterilize by autoclaving for $20 \mathrm{~min}$ at $15 \mathrm{psi}\left(1.05 \mathrm{~kg} / \mathrm{cm}^{2}\right)$. Allow the solution to cool to $\sim 60^{\circ} \mathrm{C}$ and add $100 \mathrm{~mL}$ of sterile phosphate buffer. Store $\mathrm{TB}$ at room temperature; it will keep for at least $1 \mathrm{yr}$.

Yeast Extract-Peptone-Dextrose (YEPD)

Reagent

Quantity

Bacto peptone

Yeast extract

Dextrose

Agar (optional)

G418 (200 mg/mL; optional)

$\begin{array}{rl}20 \mathrm{~g} & 2 \%(\mathrm{w} / \mathrm{v}) \\ 10 \mathrm{~g} & 1 \%(\mathrm{w} / \mathrm{v}) \\ 20 \mathrm{~g} & 2 \%(\mathrm{w} / \mathrm{v}) \\ 20 \mathrm{~g} & 2 \%(\mathrm{w} / \mathrm{v}) \\ 1 \mathrm{~mL} & 200 \mathrm{mg} / \mathrm{L}\end{array}$

Add $1 \mathrm{~L}$ of deionized water to $20 \mathrm{~g}$ bacto peptone, $10 \mathrm{~g}$ yeast extract, and $20 \mathrm{~g}$ dextrose (and $20 \mathrm{~g}$ of agar for YEPD plates). Sterilize by autoclaving for $20 \mathrm{~min}$ at $15 \mathrm{psi}\left(1.05 \mathrm{~kg} / \mathrm{cm}^{2}\right)$. To prepare YEPD plus G418 plates, allow the solution to cool to $\sim 60^{\circ} \mathrm{C}$, add $1 \mathrm{~mL}$ of G418 stock solution, and pour into Petri dishes ( $\sim 25 \mathrm{~mL}$ per 100-mm plate). Store YEPD medium without G418 at room temperature, and store YEPD containing medium G418 at $4^{\circ} \mathrm{C}$.

\section{ACKNOWLEDGMENTS}

This work was supported by grants HHMI 55007643, CIHR MOP-130358, and Ministry of Research and Innovation GL-01-022 to B.A. and C.B. and a CIHR fellowship held by J.v.L.

\section{REFERENCES}

Alting-Mees MA, Short JM. 1989. pBluescript II: Gene mapping vectors. Nucleic Acids Res 17: 9494.

Bahler J, Wu JQ, Longtine MS, Shah NG, McKenzie A 3rd, Steever AB, Wach A, Philippsen P, Pringle JR. 1998. Heterologous modules for efficient and versatile PCR-based gene targeting in Schizosaccharomyces pombe. Yeast 14: 943-951.

Chen X, Yuan H, He W, Hu X, Lu H, Li Y. 2005. Construction of a novel kind of expression plasmid by homologous recombination in Saccharomyces cerevisiae. Sci China C Life Sci 48: 330-336.

Gibson DG. 2009. Synthesis of DNA fragments in yeast by one-step assembly of overlapping oligonucleotides. Nucleic Acids Res 37: 6984-6990.

Gibson DG, Benders GA, Andrews-Pfannkoch C, Denisova EA, BadenTillson H, Zaveri J, Stockwell TB, Brownley A, Thomas DW, Algire MA, et al. 2008a. Complete chemical synthesis, assembly, and cloning of a Mycoplasma genitalium genome. Science 319: 1215-1220.

Gibson DG, Benders GA, Axelrod KC, Zaveri J, Algire MA, Moodie M, Montague MG, Venter JC, Smith HO, Hutchison CA 3rd. 2008b. One-step assembly in yeast of 25 overlapping DNA fragments to form a complete synthetic Mycoplasma genitalium genome. Proc Natl Acad Sci 105: 20404-20409.

Gietz RD, Woods RA. 2002. Transformation of yeast by lithium acetate/ single-stranded carrier DNA/polyethylene glycol method. Methods Enzymol 350: 87-96.

Kuijpers NG, Solis-Escalante D, Bosman L, van den Broek M, Pronk JT, Daran JM, Daran-Lapujade P. 2013. A versatile, efficient strategy for assembly of multi-fragment expression vectors in Saccharomyces cerevisiae using 60 bp synthetic recombination sequences. Microb Cell Fact 12: 47.

Liang X, Peng L, Tsvetanova B, Li K, Yang JP, Ho T, Shirley J, Xu L, Potter J, Kudlicki W, et al. 2012. Recombination-based DNA assembly and mutagenesis methods for metabolic engineering. Methods Mol Biol 834: 93-109.

Ma H, Kunes S, Schatz PJ, Botstein D. 1987. Plasmid construction by homologous recombination in yeast. Gene 58: 201-216.

Shao Z, Zhao H. 2009. DNA assembler, an in vivo genetic method for rapid construction of biochemical pathways. Nucleic Acids Res 37: e16.

Shao Z, Zhao H. 2013. Construction and engineering of large biochemical pathways via DNA assembler. Methods Mol Biol 1073: 85-106.

Sikorski RS, Hieter P. 1989. A system of shuttle vectors and yeast host strains designed for efficient manipulation of DNA in Saccharomyces cerevisiae. Genetics 122: 19-27.

Tan G, Tan C. 2010. SMC, a simple method to rapidly assemble multiple fragments into one construct. Front Biosci (Elite Ed) 2: 1105-1114.

Tsvetanova B, Peng L, Liang X, Li K, Yang JP, Ho T, Shirley J, Xu L, Potter J, Kudlicki W, et al. 2011. Genetic assembly tools for synthetic biology. Methods Enzymol 498: 327-348.

van Leeuwen JS, Andrews BJ, Boone C, Tan G. 2015. Construction of multifragment plasmids by homologous recombination in yeast. Cold Spring Harb Protoc doi: 10.1101/pdb.top084111.

Wang PL. 2000. Creating hybrid genes by homologous recombination. Dis Markers 16: 3-13. 


\section{Rapid and Efficient Plasmid Construction by Homologous Recombination in Yeast}

Jolanda van Leeuwen, Brenda Andrews, Charles Boone and Guihong Tan

Cold Spring Harb Protoc; doi: 10.1101/pdb.prot085100

\begin{tabular}{|c|c|}
\hline $\begin{array}{l}\text { Email Alerting } \\
\text { Service }\end{array}$ & Receive free email alerts when new articles cite this article - click here. \\
\hline $\begin{array}{l}\text { Subject } \\
\text { Categories }\end{array}$ & $\begin{array}{l}\text { Browse articles on similar topics from Cold Spring Harbor Protocols. } \\
\text { Cloning By PCR ( } 30 \text { articles) } \\
\text { High-Capacity Vectors ( } 44 \text { articles) } \\
\text { High-Capacity Vectors, general ( } 25 \text { articles) } \\
\text { Plasmids (154 articles) } \\
\text { Polymerase Chain Reaction (PCR) (139 articles) } \\
\text { YACs (13 articles) } \\
\text { Yeast (288 articles) }\end{array}$ \\
\hline
\end{tabular}

